\title{
Sistem Informasi Pemasaran Hasil Pertanian Polinela Berbasis JSON
}

\author{
Dwirgo Sahlinal ${ }^{1}$, Rima Maulini² ${ }^{2}$ Dewi Kania Widyawati ${ }^{3}$ \\ ${ }^{1}$ Program Studi Management Informatika Politeknik Negeri Lampung \\ ${ }^{2}$ Program Studi Management Informatika Politeknik Negeri Lampung \\ ${ }^{3}$ Program Studi Management Informatika Politeknik Negeri Lampung \\ ${ }^{1}$ dwirgo_sahlinal@polinela.ac.id \\ 2 rima_maulini@polinela.ac.id \\ ${ }^{3}$ dewi_mi@polinela.ac.id
}

\begin{abstract}
Agricultural information system aims to build a marketing system based on JSON information system technology (Java Script Object Notation). Specifically the research aims: (1) build a database using JSON; (2) establish marketing information system of agricultural products; (3) provide information on the implementation of identification, inventory monitoring of agricultural product marketing issues. The research begins with literature review, planning and preparation of system model, model verification, field trial, evaluation and development and implementation result. Output targets to be generated: (1) basic data of agricultural product marketing processing; (2) built a marketing information analysis system with JSON-based information technology.
\end{abstract}

Keywords: Information System; Marketing; Agricultural Product; JSON.

\begin{abstract}
Abstrak
Sistem informasi hasil pertanian bertujuan membangun sistem pemasaran berbasis teknologi sistem informasi JSON (Java Script Object Notation). Secara khusus penelitian bertujuan: (1) membangun database dengan menggunakan JSON; (2) membangun sistem informasi pemasaran hasil pertanian; (3) memberikan informasi pelaksanaan identifikasi, inventarisasi pemantauan permasalahan pemasaran hasil pertanian.Penelitian dimulai dengan kajian literatur, perencanaan dan penyusunan model sistem, verifikasi model, ujicoba lapangan, evaluasi dan pengembangan serta hasil implementasi. Target luaran yang akan dihasilkan: (1) diperoleh data dasar pengolahan pemasaran hasil pertanian; (2) dibangun sistem informasi analisa pemasaran dengan teknologi informasi berbasis JSON.
\end{abstract}

Kata Kunci : Sistem Informasi; Pemasaran; Hasil Pertanian; JSON.

\section{PENDAHULUAN}

Pentingnya informasi pasar yang akurat dan up to date bagi para pelaku pasar itulah, penelitian yang berjudul Sistem Informasi Pemasaran Hasil Pertanian POLINELA Berbasis JSON (Java Script Object Notation). Sistem ini akan dikembangkan sebagai sebuah sistem yang terpadu, yang mengintegrasikan informasi pasar komoditas hasil pertanian di Polinela. Penelitian ini juga diharapkan akan menghasilkan sebuah sistem yang mampu memperkuat jaringan informasi pasar komoditas hasil pertanian, menyediakan informasi secara cepat, tepat sasaran, akurat dan dapat dipertanggungjawabkan, baik untuk petani, pedagang, pembeli maupun pemerintah atau pihak-pihak lain yang terkait dengan kebijaksanaan pasar komoditas hasil-hasil pertanian.

Sistem informasi pemasaran jika didefinisikan dalam arti luas adalah kegiatan perseorangan dan organisasi yang memudahkan dan mempercepat bubungan pertukaran yang memuaskan dalam lingkungan yang dinamis melalui penciptaan pendistribusian promosi dan penentuan harga barang, jasa dan gagasan. Sistem informasi pemasaran 
selalu digunakan oleh bagian pemasaran dalam sebuah perusahaan untuk memasarkan produk-produk perusahaan tersebut. Sistem informasi ini merupakan gabungan dari keputusan yang berkaitan dengan 4P yaitu:

- Produk (product): produk apa yang dibeli pelanggan untuk memuaskan kebutuhannya.

- Promosi (Promotion): Meningkatkan atau mendorong penjualan.

- Tempat (Place): Cara mendistribusikan produk secara fisik kepada pelanggan melalui saluran distribusi.

- Harga (Price) : Terdiri dari semua element yang berhubungan dengan apa yang dibayar oleh pelanggan.

Java Script Object Notation (JSON) merupakan salah satu format pertukaran data yang memiliki format penulisan yang sederhana dan berkonsekuensi pada ukuran file yang dihasilkan. Ukuran file yang dihasilkan oleh JSON sangat kecil, sehingga dapat diakses dengan waktu yang relatif cepat. Dalam kaitannya sebagai penghubung komunikasi aplikasi client dengan aplikasi server, web service menggunakan suatu format serialisasi data untuk mengirimkan data. Sebelum data dikirimkan, baik dari client menuju server atau sebaliknya, harus diubah dalam format data tertentu dahulu sesuai dengan web service yang digunakan. Jenis format serialisasi data yang digunakan dalam web service diantaranya XML dan JSON.

Salah satu faktor yang mempengaruhi kemampuan format data adalah seberapa cepat request itu diproses, sehingga dibutuhkan request dengan format pertukaran data yang efisien dan cepat dalam proses parsing tersebut. XML merupakan format pertukaran data yang umum digunakan dalam aplikasi dengan berbasis web. Namun hal ini bukanlah cara yang terbaik. $X M L$ memiliki sintaks yang komplek dan harus diproses menjadi Document Object Model. Format pertukaran data selain XML yaitu JSON yang merupakan bagian dari Java Script sehingga parsing dilakukan oleh Java Script tersebut dan memiliki sintaks yang lebih sederhana dari pada $X M L$. Secara spesifikasi JSON lebih baik dari pada $X M L$.

\section{KERANGKA TEORI}

Menurut Ahmad, JSON (Java Script Object Notation) merupakan format pertukaran data berdasarkan notasi Java Script. Dari beberapa sumber mengatakan bahwa JSON lebih baik dari XML sebagai format pertukaran data. Ahmad mencoba untuk membuat uji untuk membandingkan kedua format data tersebut pada ASP.NET Web Service. Parameter pembanding yang digunakan yaitu besar stream yang ditransmisikan dan response time. Untuk menganalisis kinerja keduanya digunakan tool buatan Nikhil Kotari yaitu Web Development Helper. Pertama dibuat sebuah object Employee dengan data EmpId, Name, Sex dan Title. Object ini yang akan diserialisasi ke JSON dan $X M L$ sebagai return value Web Service. Dari hasil uji tersebut, format XML memerlukan 226 byte sedangkan JSON hanya 132 byte. Ini jauh lebih kecil (kurang dari setengah) dibandingkan XML. Dari sisi response time, pada invoke yang pertama $X M L$ membutuhkan waktu 0:0:3430 sedangkan JSON 0:0:3280 dan invoke berikutnya untuk XML 0:0:0150 sedangkan JSON 0:0:0000. Dari data ini membuktikan bahwa JSON memang lebih ringan dibandingkan $X M L$ baik dari sisi ukuran stream yang ditransmisikan lebih kecil maupun waktu proses di server juga lebih singkat.

Menurut Xiaopeng, Objek data berbasis $X M L$ pada transmisi jaringan memiliki pembacaan yang baik dan scalability. Tetapi, browser dan pendekatan codec membatasi penerapan XML. JSON adalah objek yang memilki format yang kompak. Programmer dapat menggunakan sintaks berorientasi obyek untuk mem-parsing objek data. Pada aplikasi dimasa depan, $X M L$ akan sepenuhnya diganti dengan $J S O N$ pada kriteria tertentu.

Majid Khosravi, melakukan penelitian dengan mengkoneksikan device mobile android ke web service REST untuk mengukur delay time yang terjadi pada XML dan JSON dari segi jumlah objek data, ukuran data, loading time, parsing time dengan menyediakan operasi select, update, insert dan delete. Dalam penelitian tersebut, JSON 
mempunyai respon time yang lebih cepat jika dibandingkan dengan $X M L$ ketika jumlah objek data kecil (dibawah 1300).

Nurzhan Nurseitov, melakukan studi kasus membandingkan perbedaan antara dua format pertukaran data, yaitu JSON dan XML . Dalam menganalisa hasil digunakan pengamatan kualitatif dan menganalisa lebih lanjut tiap-tiap hasil pengukuran yang signifikan diuji dengan mengunakan uji statistik, yaitu t-test. Hasilnya menunjukkan bahwa JSON lebih cepat dan menggunakan sumber daya yang lebih sedikit daripada XML. JSON dan XML mempunyai keunikan tersendiri, tetapi pentingnya kinerja dan pemanfaatan sumber daya harus dipahami ketika membuat keputusan pemilihan antara format pertukaran data.

\section{METODOLOGI}

\subsection{Rancangan Penelitian}

Rancangan penelitian yang digunakan dalam penelitian ini adalah rancangan penelitian kualitatif. Metode penelitian ini terdiri dari beberapa tahapan, yaitu tahapan pengembangan sistem dan pengumpulan data atau informasi. Sedangkan dalam pengumpulan data adalah dengan metode wawancara dan observasi langsung. Bahan atau data yang digunakan dalam penelitian ini adalah sebagai berikut : Data spasial berupa data hasil pertanian di Polinela, data non spasial yang digunakan adalah data primer (survei lapangan) dan data sekunder dari literatur mengenai data hasil pertanian, foto objek sebagai dokumentasi.

\subsection{Tahapan Penelitian}

Penelitian ini dikhususkan untuk menyimpan data pada database. Berdasarkan Conolly dan Begg (2015) tahapan database sistem development lifecycle memiliki 13 tahapan yaitu database planning, system definition, requirements collection andanalysis, database design, DBMS selection, application design, prototyping (optional), implementation, data conversion and loading,testing, dan operational maintenance. Pada penelitian ini akan mengadopsi enam tahapan awal yaitu database planning, system definition, requirement collection and analysis, database design, DBMS selection, dan implementation. Tahapan penelitian dapat dilihat di Gambar 1.

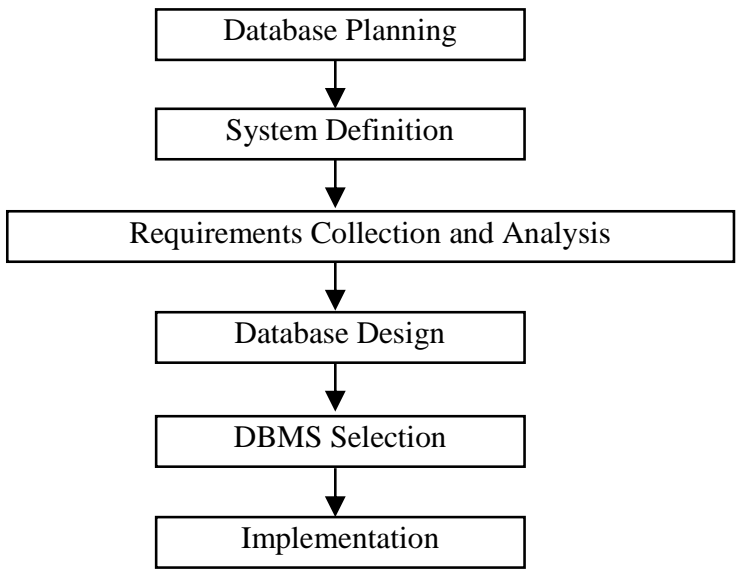

Gambar 1. Database System Development Lifecycle (mengadopsi dari Connolly dan Begg 2015) 


\section{Database planning}

Pengumpulan tujuan umum dari pengembangan database dan fungsi-fungsi apa saja yang perlu dipenuhi database untuk memenuhi kebutuhan.

2. System definition

Identifikasi cakupan dan batasan sistem database, serta mendefinisikan kebutuhan database dari berbagai sudut pandang pengguna.

3. Requirement collection and analysis

Proses pengumpulan dan analisis informasi mengenai organisasi untuk mendukung sistem database, kemudian menggunakan informasi tersebut untuk mengidentifikasi kebutuhan database baru. Kebutuhan untuk tiap pengguna terdiri dari deskripsi data yang digunakan/dihasilkan serta detail bagaimana suatu data digunakan/dihasilkan

4. Database design

Tidak seperti SQL dimana skema table harus ditentukan sebelum insert data, pada JSON tidak memiliki struktur dokumen, sehingga fleksibel dalam memetakan dokumen ke dalam entitas maupun objek. Design dari model data mengikuti penggunaan data pada sistem.

\section{DBMS selection}

Memilih database yang sesuai dengan kebutuhan dari sistem

\section{Implementation}

Proses implementasi database ke organisasi yang membutuhkan database.

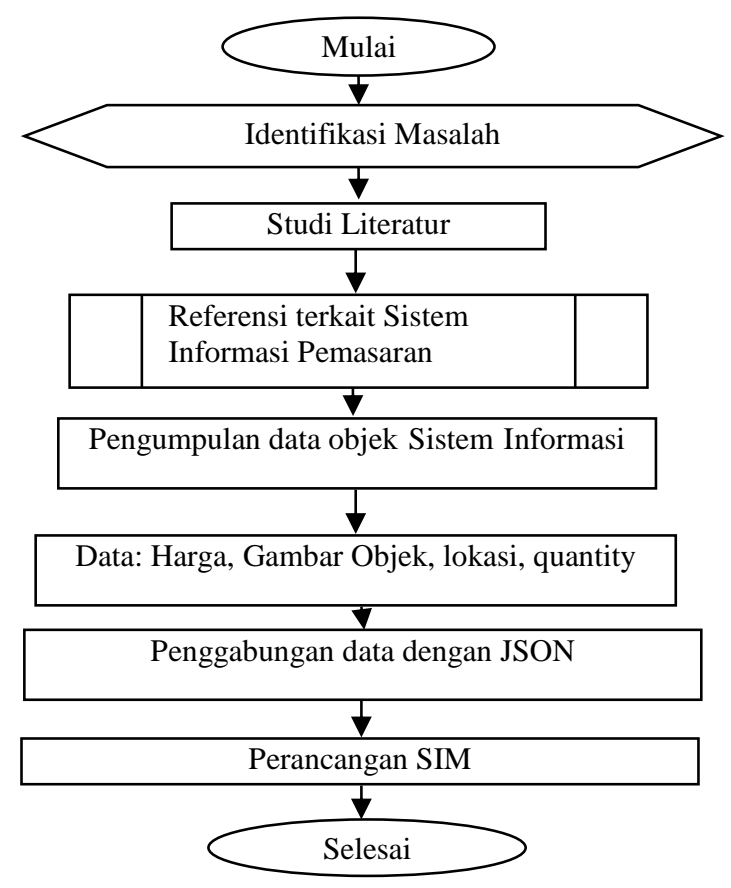

Gambar 2. Diagram Alir Penelitian 


\subsection{Metode Penelitian}

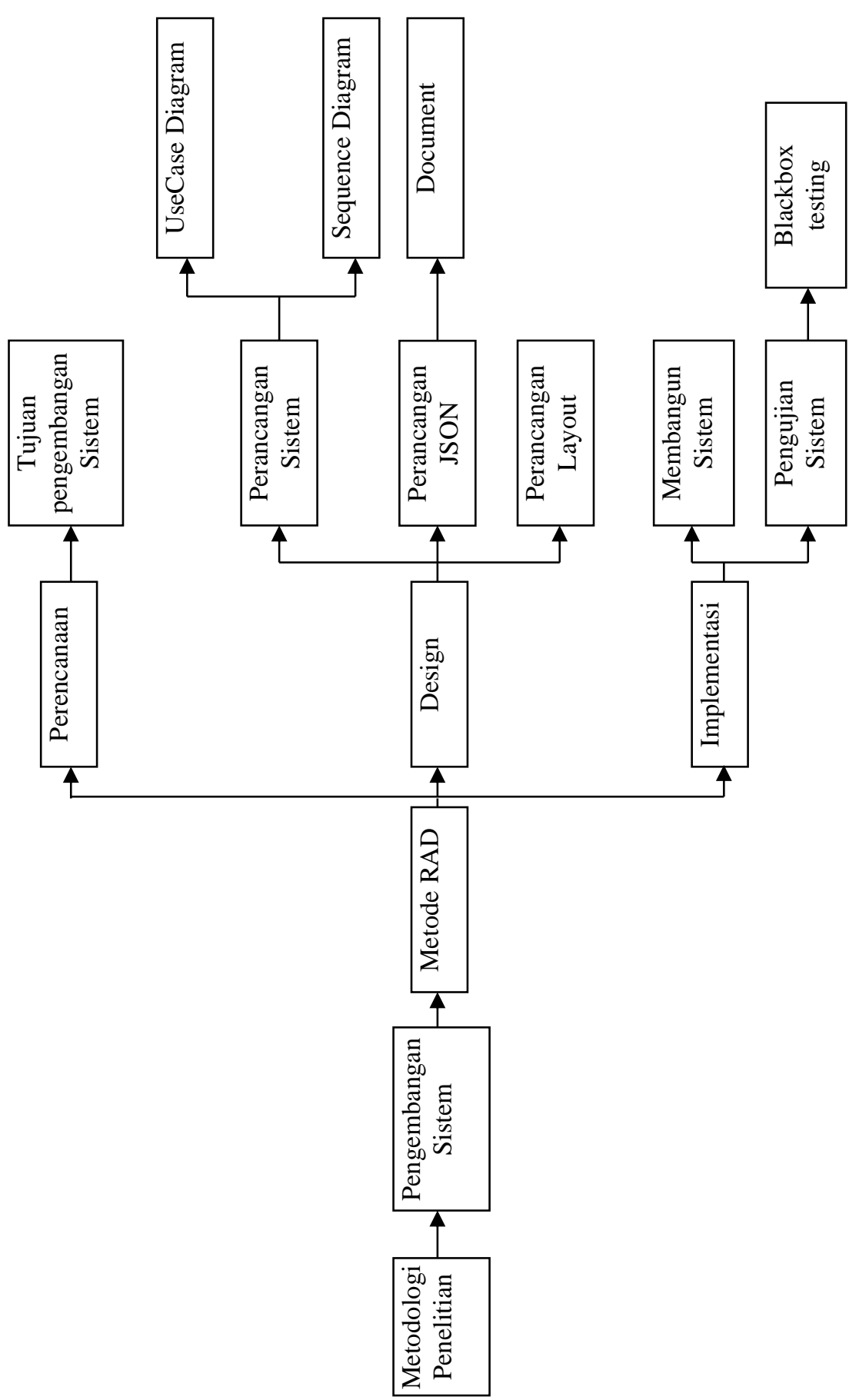

Gambar 3. Diagram Alir Pengolahan Data

\subsubsection{Perancangan Sistem}

\section{a. Use Case Diagram}

Sistem yang akan dibangun memiliki dua aktor yang akan terinteraksi langsung dengan sistem. Kedua aktor tersebut adalah Admin dan User. Aktor Admin bertugas untuk menambah user, menambah produk, mengedit 
produk, menghapus produk, melihat jenis produk dan harga produk pada sistem. Sedangkan User dapat melihat jenis produk dan harga produk. Gambar 4 dan 5 menunjukkan diagram use case untuk admin dan user.

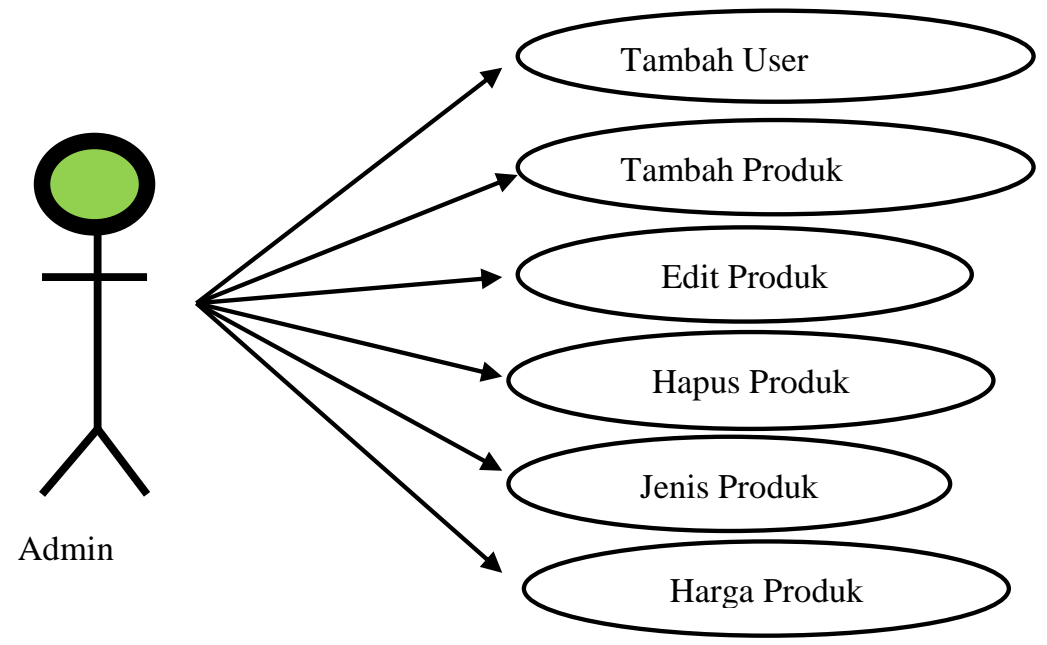

Gambar 4. Diagram Use Case Admin

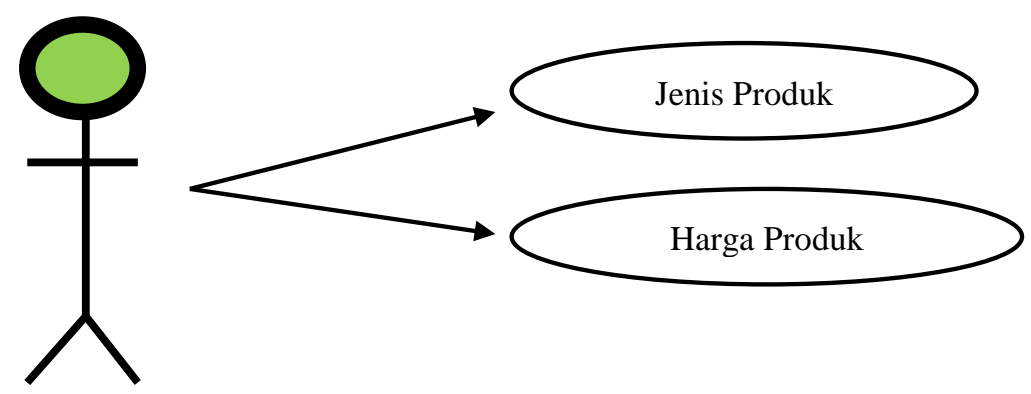

User

Gambar 5. Diagram Use Case User

\section{b. Sequence Diagram}

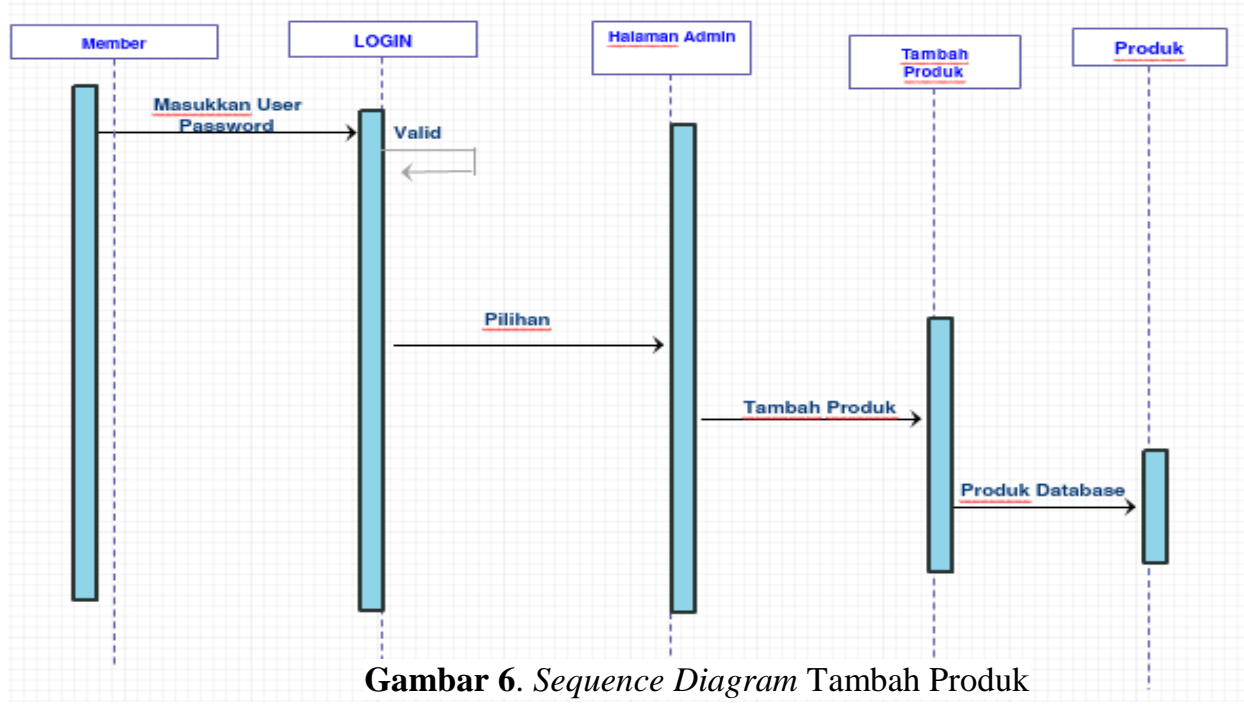




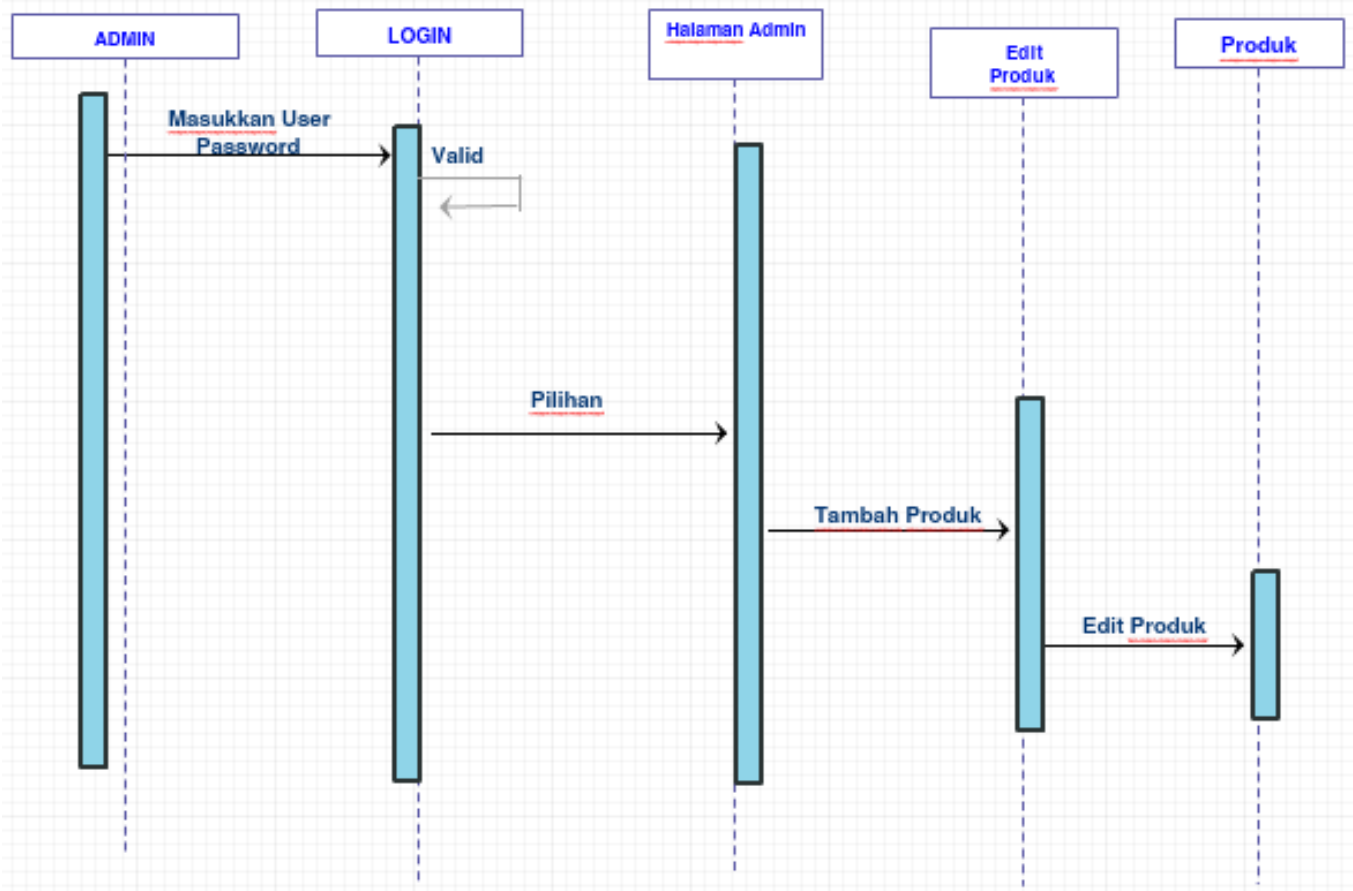

Gambar 7. Sequence Diagram Edit Produk

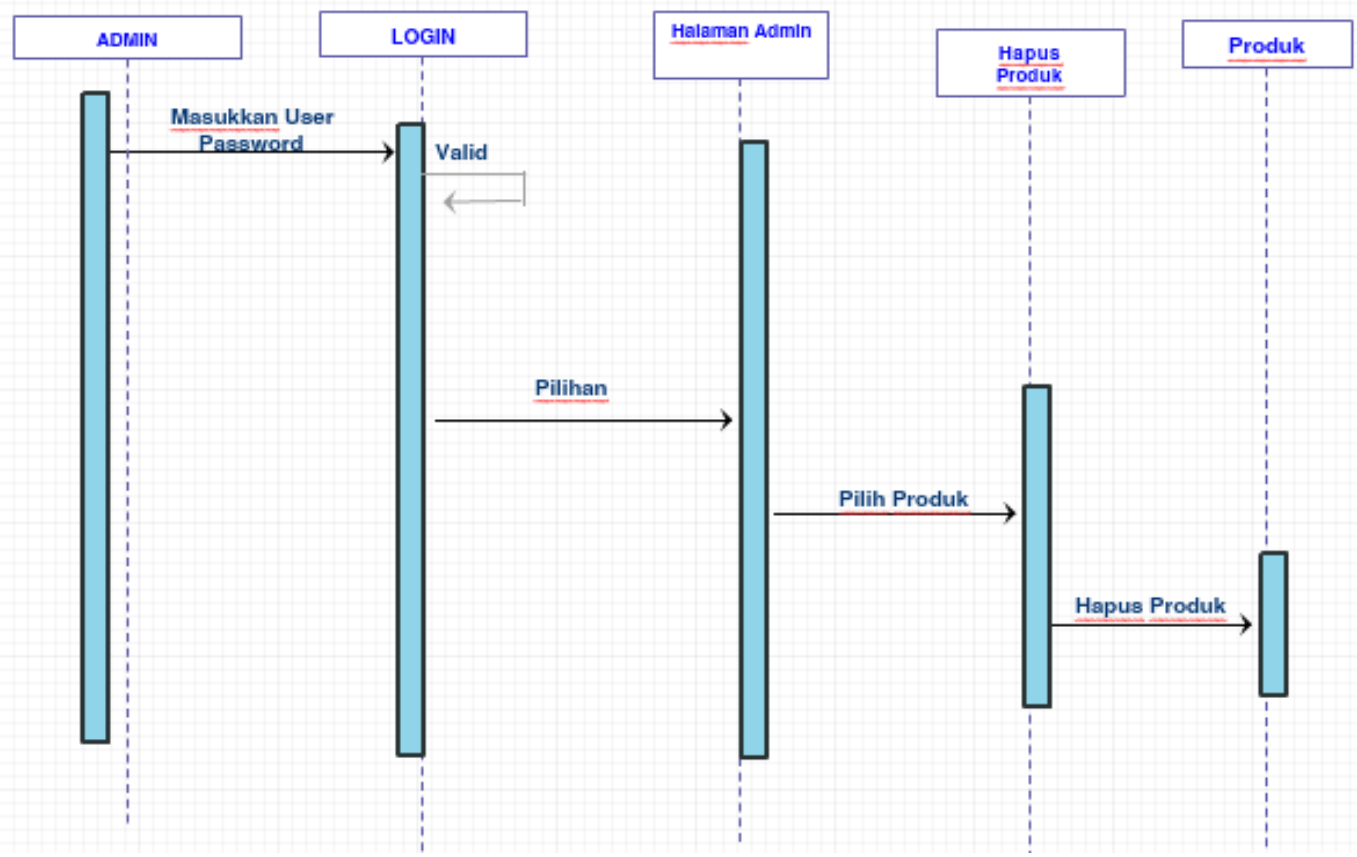

Gambar 8. Sequence Diagram Hapus Produk

\subsubsection{Perancangan JSON}

Data JSON contoh tentang hasil pertanian source code adalah:

$\{$ "records":

[

\{"kode_produk":"M001","nama_produk":"Wortel","harga":"12000",

"ketersediaan":"Terjual","gambar_produk":"wortel2.jpg","id":0 \} ,

\{"kode_produk":"M002","nama_produk":"Selada","harga":"7000",

"ketersediaan":"Tersedia","gambar_produk":"selada2.jpg","id":1

\} ,

\{"kode_produk":"M003","nama_produk":"Bayam","harga":"9000", 


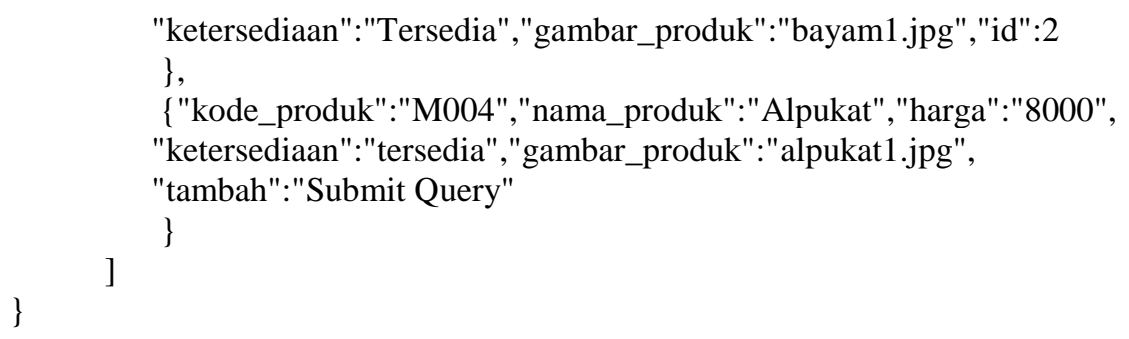

Records adalah adalah array JSON. Array terdiri dari beberapa object. Dalam penelitian ini, menggunakan 4 object records. Masing masing object record ini mempunyai 6 field.

Data JSON contoh tentang username dan password source code adalah:

[

\{ "id":0,"user":"admin","password":"admin","nama lengkap":"dwirgo",

"alamat":"kaliawi","jenis kelamin":"laki-laki"

\}

\{"id":1,"user":"","password":"" \},\{"id":2,"user":"inal","password":"inal"

\}

\{ "user":"malani","password":"malani","nama lengkap":null,

"alamat":"a","jenis kelamin":"perempuan","level":"konsumen" \}

Array JSON terdiri dari beberapa object. Dalam penelitian ini, menggunakan 3 object. Masing masing object ini mempunyai 7 field.

\subsubsection{Pengujian Sistem}

Pengujian sistem dilakukan dengan dua metode yaitu metode black box. Metode black box bertujuan menguji kesesuaian hasil pembuatan sistem terhadap analisis kebutuhan yang telah dibuat sebelumnya. Hasil pengujian dengan metode BlackBox pada Admin ditunjukkan pada Tabel 1. Tabel tersebut menunjukkan kesesuaian antara hasil pembuatan sistem dan analisis kebutuhan sistem. Sedangkan pada Tabel 2 menunjukkan hasil pengujian terhadap User.

Tabel 1. Hasil Pengujian dengan metode Black Box pada Admin

\begin{tabular}{|c|c|c|c|}
\hline Kelas Uji & Skenario Uji & $\begin{array}{ll}\text { Hasil } & \text { yang } \\
\text { diharapkan } & \end{array}$ & Kesimpulan \\
\hline \multirow[t]{2}{*}{$\begin{array}{l}\text { Tampilan Login } \\
\text { pada admin }\end{array}$} & $\begin{array}{l}\text { Tekan tombol login } \\
\text { setelah memasukan } \\
\text { username dan password }\end{array}$ & $\begin{array}{l}\text { Tampil Menu Utama } \\
\text { Yaitu Pertanian dan } \\
\text { Daftar User }\end{array}$ & Berhasil \\
\hline & Tekan tombol registrasi & Tampil isian registrasi & Berhasil \\
\hline \multirow[t]{4}{*}{ Menu Utama } & Tekan tombol Pertanian & $\begin{array}{l}\text { Tampil Jenis } \\
\text { Tanaman Pertanian }\end{array}$ & Berhasil \\
\hline & $\begin{array}{l}\text { Tekan tombol produk | } \\
\text { lihat produk }\end{array}$ & Tampil lihat produk & Berhasil \\
\hline & $\begin{array}{l}\text { Tekan tombol produk | } \\
\text { tambah produk }\end{array}$ & $\begin{array}{l}\text { Tampil tambah } \\
\text { produk }\end{array}$ & Berhasil \\
\hline & $\begin{array}{l}\text { Tekan tombol hapus } \\
\text { produk }\end{array}$ & Tampil hapus produk & Berhasil \\
\hline Logout & Takan tombol logout & $\begin{array}{l}\text { Tampil ke username } \\
\text { dan password }\end{array}$ & Berhasil \\
\hline
\end{tabular}


Tabel 2. Hasil Pengujian dengan metode Black Box pada User

\begin{tabular}{|c|c|c|c|c|}
\hline Kelas Uji & & Skenario Uji & $\begin{array}{ll}\text { Hasil } & \text { yang } \\
\text { diharapkan } & \\
\end{array}$ & Kesimpulan \\
\hline \multirow[t]{2}{*}{$\begin{array}{l}\text { Tampilan } \\
\text { pada } \text { user }\end{array}$} & \multirow[t]{5}{*}{ Login } & $\begin{array}{l}\text { Tekan tombol login } \\
\text { setelah memasukan } \\
\text { username dan } \\
\text { password }\end{array}$ & $\begin{array}{l}\text { Tampil Menu Utama } \\
\text { Yaitu Pertanian dan } \\
\text { Daftar User }\end{array}$ & Berhasil \\
\hline & & Tekan tombol registrasi & Tampil isian registrasi & Berhasil \\
\hline \multirow[t]{2}{*}{ Menu Utama } & & $\begin{array}{ll}\text { Tekan } & \text { tombol } \\
\text { Pertanian } & \end{array}$ & $\begin{array}{l}\text { Tampil Jenis } \\
\text { Tanaman Pertanian }\end{array}$ & Berhasil \\
\hline & & $\begin{array}{l}\text { Tekan tombol produk | } \\
\text { lihat produk }\end{array}$ & Tampil lihat produk & Berhasil \\
\hline Logout & & Takan tombol logout & $\begin{array}{l}\text { Tampil ke username } \\
\text { dan password }\end{array}$ & Berhasil \\
\hline
\end{tabular}

\section{HASIL DAN PEMBAHASAN}

Hasil penelitian yang dilakukan dijabarkan berdasarkan tahapan penelitian yang dikemukakan pada metodologi. Berikut merupakan beberapa tampilan antarmuka aplikasi web.

Pada sub menu lihat produk dan tambah produk akan ditampilkan contoh produk pertanian seperti gambar berikut:

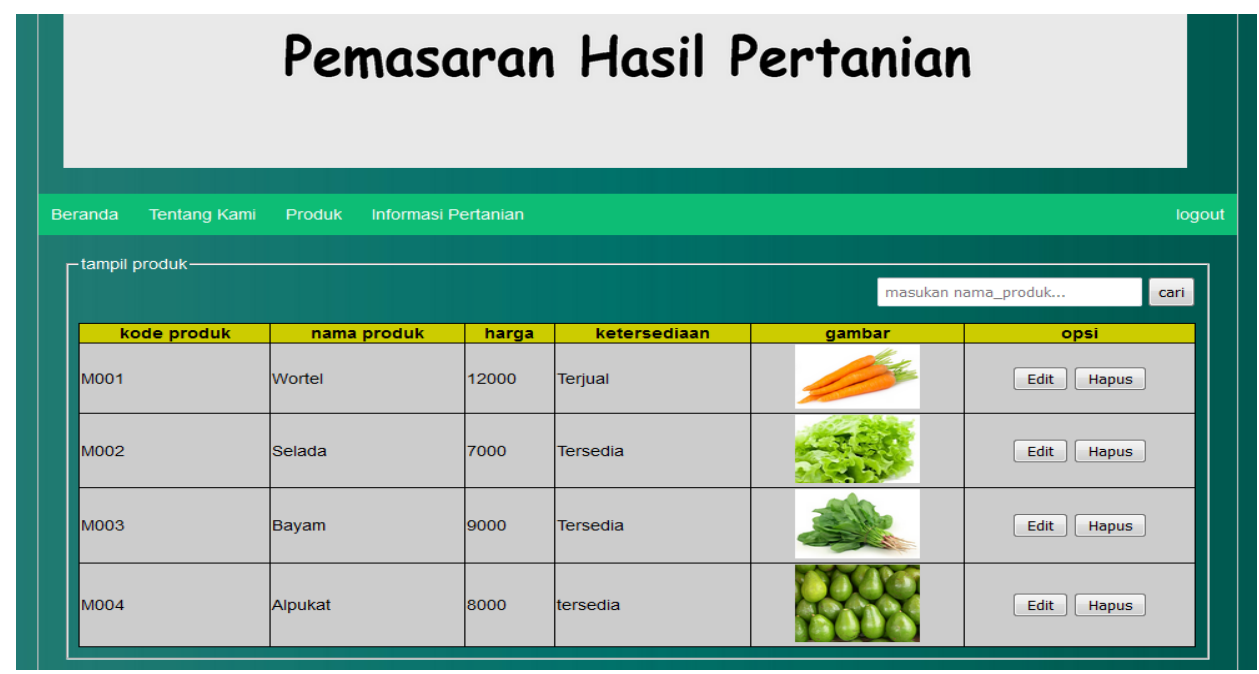

Gambar 9. Tampilan Lihat Produk Admin

Hasil penambahan produk disimpan dengan menggunakan JSON.

a. Tampilan menu produk dan sub menu lihat produk user

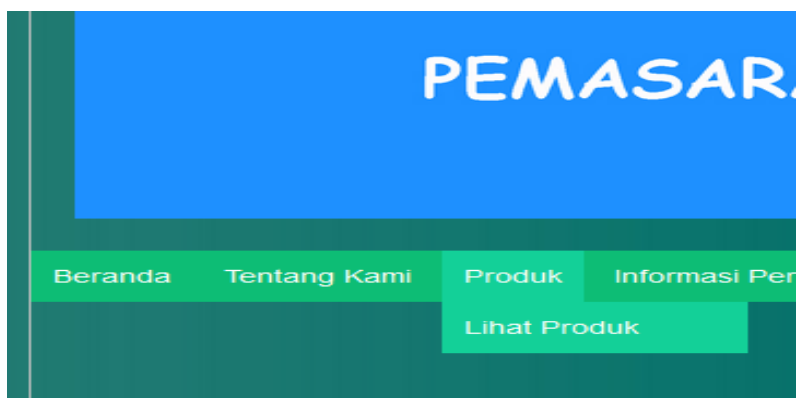

Gambar 10. Tampilan menu user 
Pada menu produk | lihat produk hanya menampilkan lihat produk pada user dengan field tabel kode produk, nama produk, harga, ketersediaan, dan gambar produk sebagai berikut

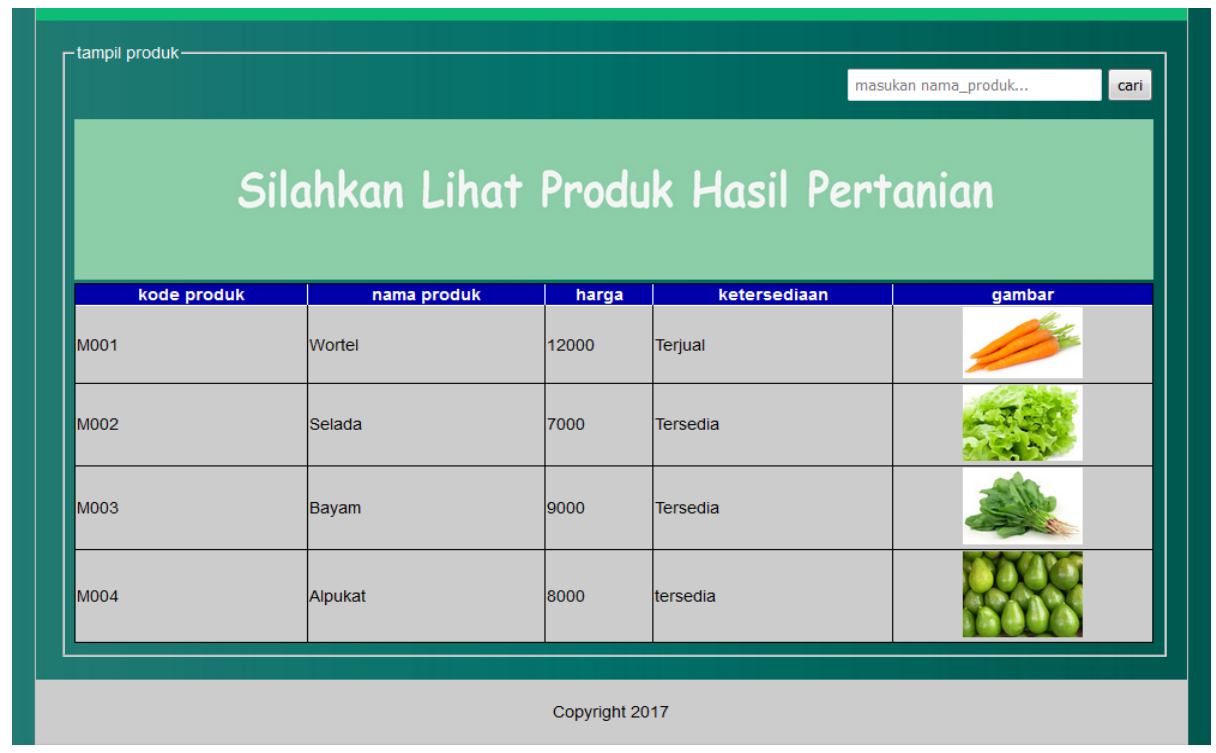

Gambar 11. Tampilan menu lihat produk pada user

Pada penelitian ini untuk melakukan proses transaksi penjualan hasil pertanian belum dilaksaksanakan dengan menggunakan JSON.

\section{KESIMPULAN}

Dari pembahasan yang diuraikan maka penyusun menarik kesimpulan sebagai berikut. Sistem Informasi Pemasaran Hasil Pertanian dengan JSON ini berhasil dibuat dan dapat dijadikan acuan mengenai harga tanaman pertanian dan perkebunan dengan mudah dan tepat dikarenakan proses aplikasi ini berjalan secara real time tanpa menggunakan database. Akan tetapi, masih akan dilakukan penelitian lanjut untuk melakukan proses transaksi penjualan hasil pertanian dengan menggunakan JSON.

\section{DAFTAR PUSTAKA}

Ahmad Masykur. 2008. JSON vs XML. http://www.masykur.web.id/post/ JSON-vs-XML.aspx. diakses tanggal April 2015

Hunlock, Patrick. 2007. "Mastering JSON (JavaScript Object Notation)”. http://www.scribd.com/doc/15009816/Mastering-in-JSON-JavaScript-Object-Notation-.

Hasibuan, Z.A., 2002, “Electronic Government for Good Governance”, Jurnal Sistem Informasi dan Manajemen Teknologi Informasi, Vol. 1, Nomor 1

Khosravi Majid.2012. “XML vs JSON parsing in Android”. http://www.majidkho sravi.com/xml-vs-json-android/. Topcu et al. "Web 2.0 for E-Science Environments”. Community Grids Laboratory, Indiana University, 501 North Morton Street, Suite 224 Bloomington, IN 47404 